\title{
Desain dan Implementasi Antena Mikrostrip VSAT Bergerak pada Frekuensi Downlink Ku Band
}

\author{
HANNY MADIAWATI, JOKO SURYANA \\ Jurusan Teknik Elektro Fakultas Teknik Telekomunikasi \\ Institut Teknologi Bandung \\ Email : hannymadiawati@gmail.com
}

\begin{abstract}
ABSTRAK
Kebutuhan sistem komunikasi satelit bergerak pada pita Ku sekarang ini mulai berkembang di Indonesia. Ku-band memiliki ketersediaan lebar pita yang besar dan memiliki panjang gelombang yang lebih pendek. Panjang gelombang yang pendek berpengaruh pada dimensi perangkat yang lebih kecil. Pada umumnya antena satelit untuk sistem yang bergerak menggunakan parabola namun penggunaannya pada kendaraan terkendala beratnya masa keseluruhan sistem sehingga diperlukan sistem kendali motor dengan harga mahal. Oleh karena itu, penggunaan antena mikrostrip dengan metode antena susun (array) menjadi solusi yang dapat memungkinkan kendaraan tetap bergerak dengan baik dengan tetap menjaga kelangsungan hubungan telekomunikasi selama bergerak. Pada penilitian ini, suatu antena mikrostrip penerima dengan menggunakan metode array dengan jumlah patch $2 \times 16$ yang mampu bekerja pada pita Ku-Band telah dirancang dan direalisasikan. Antena ini bekerja pada frekuensi $11,9 \mathrm{GHz}$ dengan gain sebesar 18,69 $d B$.
\end{abstract}

Kata kunci: komunikasi satelit, Ku-Band, antena mikrostrip, antena mikrostrip array.

\section{ABSTRACT}

Needs of mobile satellite communication system at Ku Band are currently being widely grown in Indonesia. Ku-band has a large bandwidth availability and has a shorter wavelengt. The short wavelength effect on the smaller device dimensions. In general, satellite antennas for mobile system uses parabolic antenna but if its use on vehicles the obstacle is weighing of the whole system so it takes motor control system with an expensive price. Therefor, the use of microstrip antenna by using antenna array is a solution that can allow the vehicle to keep moving well while maintaining the continuity of telecommunication links during the move. In this research, a microstrip antenna array receiver using the patch number $2 \times 16$ are able to work in the Ku-band has been design dan realized. The antenna work at $11.9 \mathrm{GHz}$ with a gain $18,69 \mathrm{~dB}$.

Keywords: satellite communication, Ku-Band, microstrip antenna, array microstrip antenna. 

Desain dan Implementasi antena VSAT bergerak dengan flat array berbasis mikrostrip pada frekuensi downlink pita Ku-band

\section{PENDAHULUAN}

Satelit komunikasi adalah salah satu tulang punggung infrastruktur telekomunikasi di Indonesia. Satelit merupakan alternatif yang tepat untuk negara yang sangat luas seperti Indonesia. Namun seiring dengan pesatnya peningkatan kebutuhan teknologi komunikasi baik untuk data, suara dan gambar, maka analisis dan desain link satelit harus dipertimbangkan dengan seksama. Pemilihan penggunaan frekuensi untuk aplikasi satelit komunikasi mulai menjadi salah satu yang paling penting.

Sekarang ini frekuensi C-band masih menjadi pilihan bagi para pengguna jasa satelit komunikasi di Indonesia. Salah satu alasannya adalah kecilnya pengaruh redaman hujan pada C-band, sehingga untuk negara yang memiliki curah hujan yang cukup tinggi seperti Indonesia ketersediaan C-band sangat tinggi. Akan tetapi terdapat beberapa masalah dalam penggunaan C-band di Indonesia yaitu bandwidth yang terbatas, interferensi dengan terestrial dan makin sempitnya separasi orbit satelit sehingga bisa menimbulkan interferensi oleh satelit yang bersebelahan. Oleh karena itu, alternatif penggunaan Ku-band mulai dilirik berbagai pihak untuk kepentingan komunikasi satelit. Beberapa keuntungan Ku-band adalah bandwidth yang lebih lebar, relatif lebih aman dari interferensi dengan terestrial dan memiliki ukuran antena yang lebih kecil.

Perkembangan teknologi komunikasi satelit dituntut mampu memberikan layanan yang sifatnya broadband kepada pelanggan. Sebuah antena yang memiliki ukuran kecil dengan gain tinggi diperlukan untuk memenuhi permintaan yang tinggi terhadap layanan komunikasi satelit ini. Namun pada antena mikrostrip, nilai gain justru yang menjadi salah satu kelemahannya. Gain didefinisikan sebagai perbandingan antara intensitas pada arah tertentu dengan intensitas radiasi yang diperoleh jika daya yang diterima oleh antena teradiasi secara isotropic. Salah satu metode untuk meningkatkan gain antena mikrostrip diantaranya metode antena susun (array) (Xiang, H., Jiang, X.,2009).

Jenis antena mikrostrip adalah suatu konduktor metal yang menempel di atas ground plane yang diantaranya terdapat bahan dielektrik. Antena mikrostrip tersusun atas 3 komponen yaitu: groundplane, substrate dan patch peradiasi (Balanis,C,A.,1982). Antena mikrostrip merupakan salah satu antena gelombang mikro yang mulai digunakan pada sejumlah sistem telekomunikasi satelit saat ini dibandingkan antena parabola yang biasanya digunakan, ini disebabkan karena antena mikrostrip memiliki beberapa keuntungan, diantaranya mempunyai bentuk yang kompak, dimensi kecil, mudah untuk difabrikasi (Xing, J \& Yiming, L.,2013). Gain dari antena mikrostrip dapat diperbesar dengan menambahkan patch secara array, sehingga membentuk antena mikrostrip array. Antena mikrostrip array adalah pengembangan dari antena mikrostrip yang merupakan gabungan dari beberapa elemen peradiasi yang membentuk suatu jaringan (Suryana, J., Sugihartono.,2013).

Oleh karena itu dalam penelitian ini, suatu antena mikrostrip dengan metode array dengan jumlah patch $2 \times 16$ dibuat dengan nilai gain $18.69 \mathrm{~dB}$ yang bekerja pada frekuensi $11,9 \mathrm{GHz}$ untuk memenuhi kebutuhan komunikasi satelit bergerak broadband yang bekerja pada pita Ku-band. Pita Ku-band ini dipilih karena dalam dunia sistem komunikasi satelit, frekuensi Cband telah penuh dan saat ini dunia menerapkan frekuensi Ku-band untuk sistem komunikasi satelit karena dengan frekuensi ini aplikasi broadband bisa lebih baik digunakan. 


\section{METODOLOGI}

\subsection{Sistem Komunikasi Satelit pada Pita Ku}

Sistem komunikasi satelit memanfaatkan sumber daya frekuensi di atas frekuensi $100 \mathrm{MHz}$ yang termasuk dalam rentang very high frequency (VHF), ultra high frequency (UHF) dan super high frequency (SHF). Rentang SHF sendiri terbagi menjadi beberapa sub-pita lagi yaitu, pita L, pita S, pita C, pita X, pita Ku dan pita Ka. Gambar dibawah ini menunjukan keseluruhan rentang spektrum frekuensi yang digunakan dalam sistem komunikasi radio.

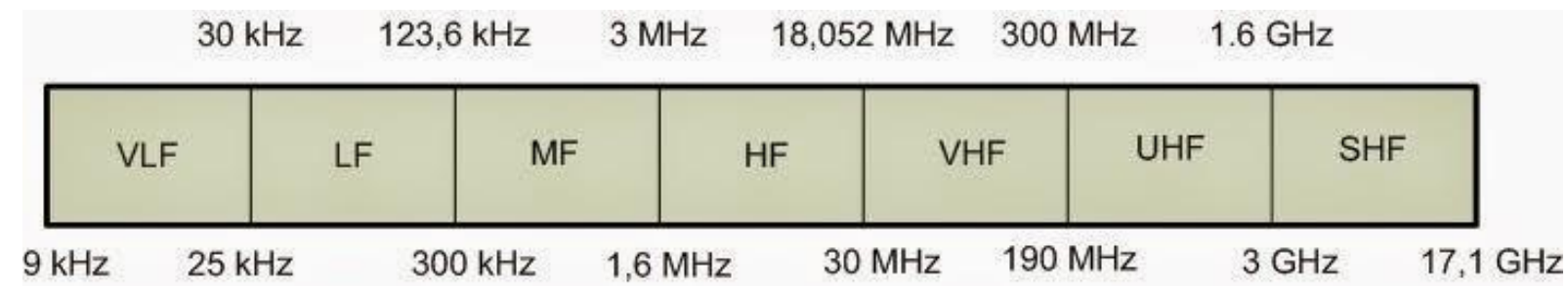

Gambar 1. Spektrum frekuensi(Hasan, 2014)

Pita Ku sendiri terletak pada rentang frekuensi $12 \mathrm{GHz}$ hingga $18 \mathrm{GHz}$. Pada umumnya, pita Ku dan pita-pita lain di bawah frekuensi tersebut lebih diminati karena biaya perangkat pada rentang frekuensi tersebut relatif rendah dan memiliki karakteristik propagasi gelombang yang lebih baik.

Perlu diperhatikan bahwa sebagian besar pita frekuensi yang digunakan pada sistem komunikasi satelit juga dapat digunakan pada sistem komunikasi terestrial. Ada beberapa pita, seperti pita Ku dan pita Ka yang seutuhnya hanya digunakan untuk komunikasi satelit dan tidak digunakan pada komunikasi terestrial. Penggunaan pita-pita frekuensi yang terbagi antara komunikasi satelit dan komunikasi terestrial ini membutuhkan koordinasi frekuensi yang biasanya diatur oleh lembaga regulasi frekuensi untuk mencegah terjadinya interferensi antar sistem komunikasi. Karena adanya kemungkinan penggunaan frekuensi yang sama dengan komunikasi terestrial, pemilihan pita frekuensi yang sepenuhnya digunakan untuk sistem komunikasi satelit saja menjadi pilihan yang diminati. Keunggulan utama penggunaan pita Ku yang dimanfaatkan dalam penerapan pada sistem yang baru adalah murahnya harga terminal dengan dimensi antena yang kecil dibandingkan dengan sistem pita $\mathrm{C}$ yang lebih populer sebelumnya.

\subsection{Teknologi Antena Mikrostrip}

Pada dasarnya, konsep mikrostrip pertama kali dikemukakan oleh Deschamps pada tahun 1953 yang kemudian dipatenkan atas nama Gutton dan Baissinot pada tahun 1955 di Perancis. Jenis antena ini mulai diproduksi secara masal pada tahun 1970 dan berkembang sangat cepat dengan didukung oleh ketersediaan bahan dasar seperti substrat dengan rugirugi disipasi yang kecil dan perbaikan teknik photolithographic sebagai teknik dasar pembuatan mikrostrip serta dikembangkannya model teoritis antena mikrostrip (James, J.,R., Hall, P,S., 1989).

Struktur antena mikrostrip seperti yang ditunjukan pada gambar 2.1 terdiri dari tebal patch yang sangat tipis ( $\mathrm{t}<<\mathrm{\lambda}$ ), dimana $\lambda \mathrm{o}$ adalah panjang gelombang di ruang bebas. Patch tersebut ditempatkan diatas ground plane. Tebal substrat, $\mathrm{h}<<\lambda_{0}$ (biasanya 0,003 $\lambda_{0} \leq \mathrm{h}$ $\leq 0,05 \lambda \mathrm{o}$ ). Untuk patch persegi, panjang dari elemen (L) biasanya $\lambda \mathrm{o} / 3<\mathrm{L}<\lambda_{0} / 2$. Patch 
dan ground plane dipisahkan oleh bahan dielektrik yang disebut substrat seperti yang ditunjukan pada Gambar 1(a) (Balanis, C.,A., 1982).

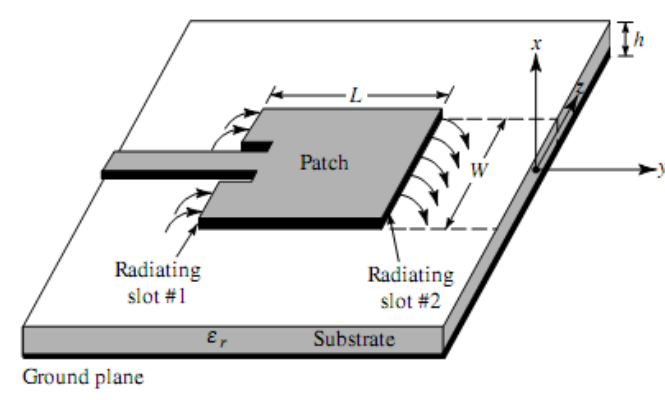

(a) Tampak Atas

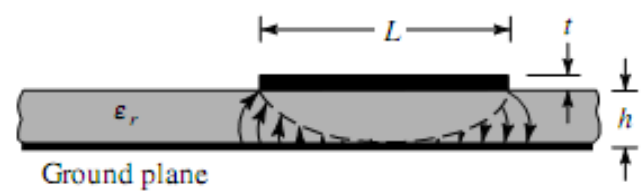

(b) Tampak Samping

Gambar 1. Struktur antena mikrostrip (Balanis, $\left.C_{,} A ., 1982\right)$

Konstruksi dari mikrostrip terdiri dari konduktor strip (line) dan sebuah konduktor bidang tanah yang dipisahkan oleh medium dielektrik dengan konstanta dielektrik (Er). Di atas strip adalah udara sehingga bila tanpa shielding sebagian medan elektromagnetik akan meradiasi, dan sebagian lagi ada yang masuk kembali ke dalam substrat dielektrik. Jadi, terdapat dua dielektrik yang melingkupi strip yaitu udara dengan konstanta dielektrik satu dan substrat dengan konstanta dielektrik $(\varepsilon r)>1$. Dengan demikian saluran mikrostrip, secara keseluruhan, dapat kita pandang sebagai sebuah saluran dengan dielektrik homogen yang lebih besar dari satu tetapi lebih kecil dari $\varepsilon$ r. Konstanta dielektrik ini disebut konstanta dielektrik efektif (effective dielectric constant) (Balanis,C,A.,1982).

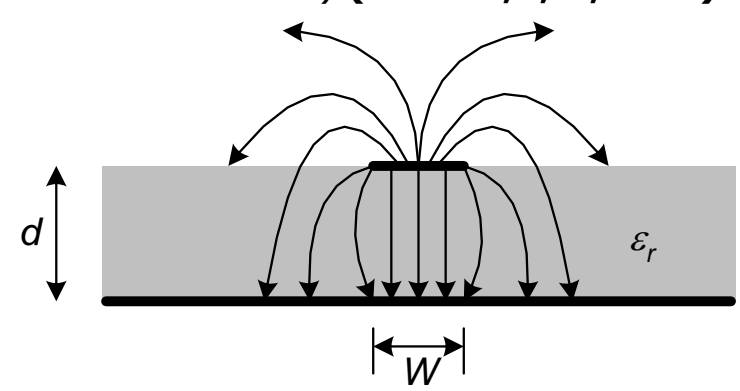

Gambar 2. Pola medan listrik pada saluran mikrostrip (Balanis,C,A.,1982).

\subsection{Mikrostrip Antena Array}

Pada banyak aplikasi diperlukan antena dengan keterarahan yang baik dan perolehan gain yang tinggi. Kebutuhan karakteristik ini dapat dipenuhi dengan menyusun antena dengan beberapa konfigurasi. Antena susunan ini sering disebut sebangai antena array. Antena array adalah susunan dari beberapa antena yang identik. Dalam antena mikrostrip yang disusun secara array adalah bagian patch. Ada beberapa macam konfigurasi antena array, di antaranya: linear, planar, dan circular. Masing-masing konfigurasi memiliki keuntungan. Planar array memiliki kelebihan dalam pengaturan dan pengendalian arah pola radiasi( Rambe \& Hanafiah, A.,2008).

\subsection{Rectangular Mikrostrip Antena}

Pada Gambar 1(a), untuk antena rectangular patch terdapat beberapa parameter yang harus diketahui sebagai perancangan dimensi antena. 
Untuk memperoleh lebar patch(W) dan panjang patch(L) menggunakan persamaan berikut (Balanis,C,A.,1982):

$$
\begin{gathered}
W=\frac{c}{2 f} \sqrt{\frac{2}{\epsilon_{r}+1}} \\
\epsilon_{e f f}=\frac{\epsilon_{r}+1}{2}+\frac{\epsilon_{r}-1}{2}\left(1+\frac{12 . h}{w}\right)^{-0.5} \\
\Delta L=0.412 . h \frac{\left(\epsilon_{e f f}+0.3\right)\left(\frac{w}{h}+0.264\right)}{\left(\epsilon_{e f f}-0.258\right)\left(\frac{W}{h}+0.813\right)} \\
L=\frac{c}{2 f \sqrt{\epsilon_{e f f}}}-2 \Delta L
\end{gathered}
$$

\subsection{Teknik Pencatuan}

Ada beberapa teknik pencatuan yang dapat digunakan untuk antena microstrip. Empat teknik yang paling populer digunakan adalah microstrip line, coaxial probe, aperture coupling, dan proximity coupling (Balanis,C,A.,1982). Teknik pencatuan yang dapat dilakukan secara langsung yaitu menggunakan teknik probe coaxial atau microstrip line. Pencatuan juga bisa dilakukan secara tidak langsung yaitu dengan menggunakan aperture coupling, dimana tidak ada kontak metalik langsung antara feed line dan patch. Teknik pencatuan mempengaruhi impedansi input dan karakteristik antena.

Semua teknik pencatuan memiliki kelebihan dan kekurangan. Pada teknik pencatuan microstrip line mempunyai karakteristik dapat di-etching-kan pada substrat yang sama sehingga struktur antena sepenuhnya planar dan mudah untuk di pabrikasi. Akan tetapi membutuhkan rangkaian penyesuai dalam menyesuaikan impedansi input dengan impedansi antena dan akan terdapat kopling antara strip line dan patch nya (Fahrazal, M., 2008).

Pada teknik pencatuan coaxial probe, konduktor pusat dari konektor coaxial langsung dihubungkan dengan patch antena lalu disolder. Keuntungan teknik ini adalah penempatan konektor bisa dimana saja pada patch untuk menghasilkan impedansi beban, dalam hal ini antena yang match, dengan impedansi input konektor sehingga tidak perlu lagi rangkaian penyesuai. Selain itu, karena kabel coaxial dihubungkan langsung dengan patch maka kopling catuan dengan patch bisa diminimalisasi. Akan tetapi akibat dilakukannya pelubangan terhadap patch, struktur antena tidak planar lagi dan tingkat keakuratan penentuan titik catu sangat tinggi sehingga sulit ditentukan.

Pada teknik pencatuan dengan menggunakan proximity coupling dapat menghasilkan bandwidth yang lebih lebar daripada menggunakan teknik pencatuan microstrip line atau coaxial probe. Konfigurasi dari teknik pencatuan ini adalah menggunakan dua lapisan substrat. Saluran transmisi (feed line) diletakan di bawah patch. Parameter dari kedua lapisan substrat dapat dipilih untuk meningkatkan bandwith antena, dan mengurangi radiasi elemen pencatu. Untuk keperluan ini tebal substrat bagian bawah harus tipis. Dengan meletakkan patch peradiasi diatas dua lapisan substrat maka akan dihasilkannya bandwith 
yang lebar. Hal ini dikarenakan dengan menggunakan dua lapisan maka ketebalan substrat yang digunakan menjadi lebih tebal.

Pada teknik pencatuan aperture coupling plat konduktor yang mempunyai aperture untuk melewatkan energi ke antena. Substrat yang diatas dapat dibuat denga permitivitas yang lebih rendah dari yang dibawah untuk menghasilkan radiasi yang lebih baik. Kerugiannya adalah sulit untuk disusun/dibuat.

\subsection{Matching Impedance}

Perancangan suatu antena tidak terlepas dari penyesuaian impedansi. Suatu jalutr transmisi dikatan matched apabila karakteristik impedansi $Z_{0}=Z_{L}$, atau dengan kata lain tidak ada refleksi yang terjadi pada ujung saluran beban. $Z_{0}$ merupakan karakteristik impedansi suatu saluran transmisi dan biasanya bernilai $50 \mathrm{Ohm} . Z_{L}$ merupakan impedansi beban, beban dapat berupa antena atau rangkaian lain yang mempunyai impedansi ekivalen $Z_{L}$. Karena kegunaan utama saluran transmisi adalah untuk mentransfer daya secara sempurna, maka beban matched sangat diperlukan (Fahrazal, M., 2008).

Metode pencatuan secara langsung sulit untuk mencapai kondisi matching. Oleh karena itu dibutuhkan suatu cara untuk mendapatkan kondisi yang matching, yaitu salah satu caranya dengan menambahkan transformator $\lambda / 4$ seperti yang digunakan pada penelitian ini.

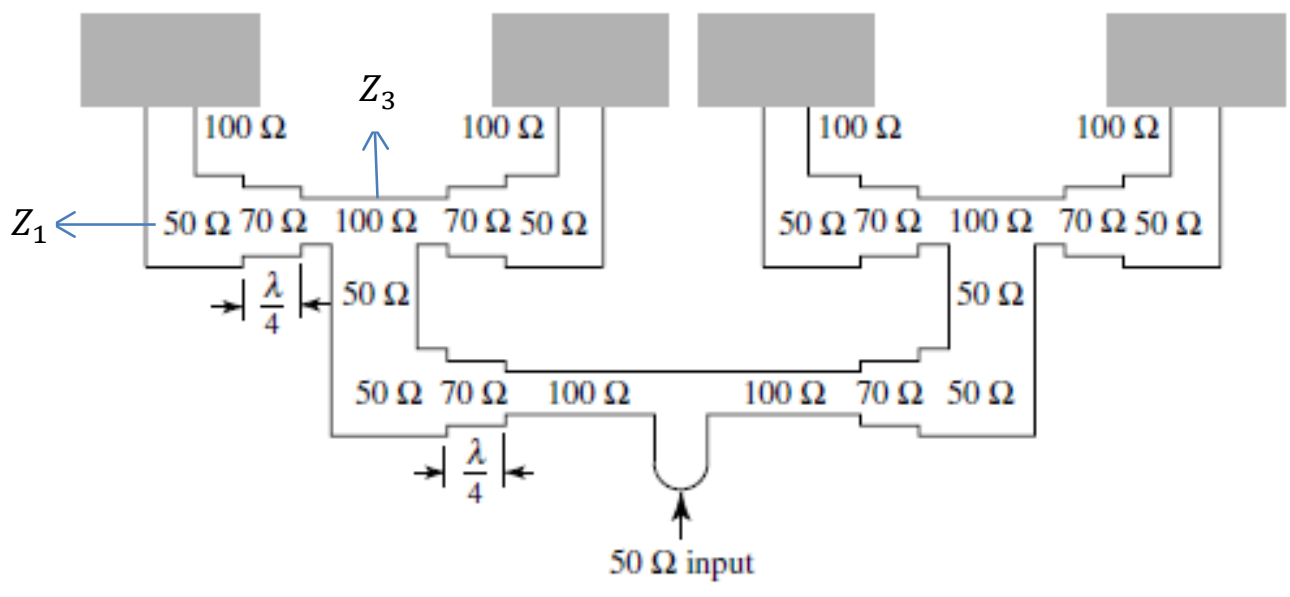

Gambar 3. Transformator $\lambda / 4$ (Balanis,C,A.,1982).

Transformator $\lambda / 4$ merupakan suatu teknik penyesuai impedansi dengan memberikan saluran transmisi dengan impedansi $Z_{T}$ di antara dua saluran transmisi yang tidak matched. Panjang sakuran transmisi transformator $\lambda / 4$ ini adalah sebesar $l=\frac{1}{4} \lambda_{g}$, dimana $\lambda_{g}$ merupakan panjang gelombang pada bahan dielektrik yang besarnya dapat dihitung pada persamaan berikut:

$$
\lambda_{g}=\frac{\lambda_{0}}{\sqrt{\varepsilon_{e f f}}}
$$

Dimana $\lambda_{0}$ adalah panjang gelombang pada ruang bebas. Nilai impedansi $Z_{T}$ dapat dihitung dengan menggunakan persamaan berikut:

$$
Z_{T}=\sqrt{Z_{1} Z_{3}}
$$




\subsection{Hasil perhitungan}

\section{HASIL DAN PEMBAHASAN}

Antena mikrostrip array 2x16 untuk aplikasi Ku-band ini memiliki spesifikasi sebagai berikut:

Tabel 1. Spesifikasi antena mikrostrip

\begin{tabular}{|l|l|}
\hline Bentuk antena & Rectangular \\
\hline Bahan Substrat & FR4-Epoxy $(\varepsilon \mathrm{r}=4,4)$ \\
\hline Ketebalan Substrat (h) & $1,6 \mathrm{~mm}$ \\
\hline Ketebalan Tembaga (t) & $0,035 \mathrm{~mm}$ \\
\hline Frekuensi Kerja (fo) & $11.97 \mathrm{GHz}$ \\
\hline Bandwidth & $600 \mathrm{MHz}$ \\
\hline Polarisasi & Linier \\
\hline VSWR & $0 \leq \mathrm{VSWR} \leq 2$ \\
\hline Gain & $\geq 16 \mathrm{~dB}$ \\
\hline
\end{tabular}

Setelah menentukan spesifikasi yang akan dirancang maka langkah selanjutnya adalah melakukan perhitungan berdasarkan rumus (1) dan (4) dan didapatkan nilai $W=7,089 \mathrm{~mm}$ dan $\mathrm{L}=5.78 \mathrm{~mm}$. Hasil perhitungan parameter antena ini kemudian akan diimpelementasikan dengan menggunakan sebuah software simulator 3D.

\subsection{Hasil simulasi}

Berikut adalah desain antena microstrip array $2 \times 16$ berbentuk rectangular.

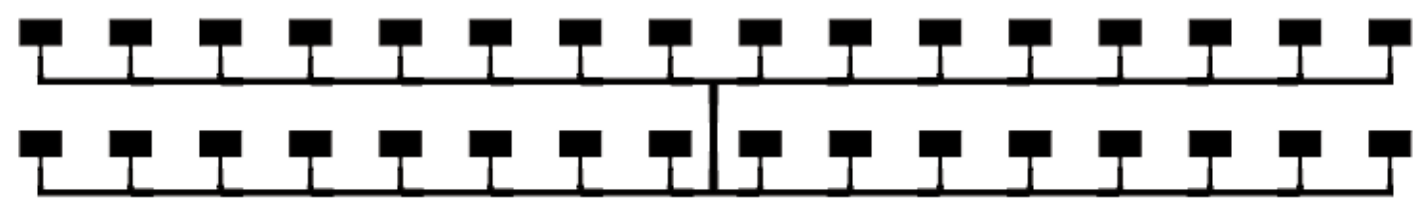

Gambar 4. Rancangan antena mikrostrip array 2x16 elemen

Parameter yang diamati untuk mengetahui kinerja antena dan kesesuaian terhadap spesifikasi yang telah ditentukan sebelumnya berdasarkan hasil simulasi, yakni nilai return loss ,VSWR dan gain antena seperti yang ditunjukan pada Gambar 5,6 dan 7.

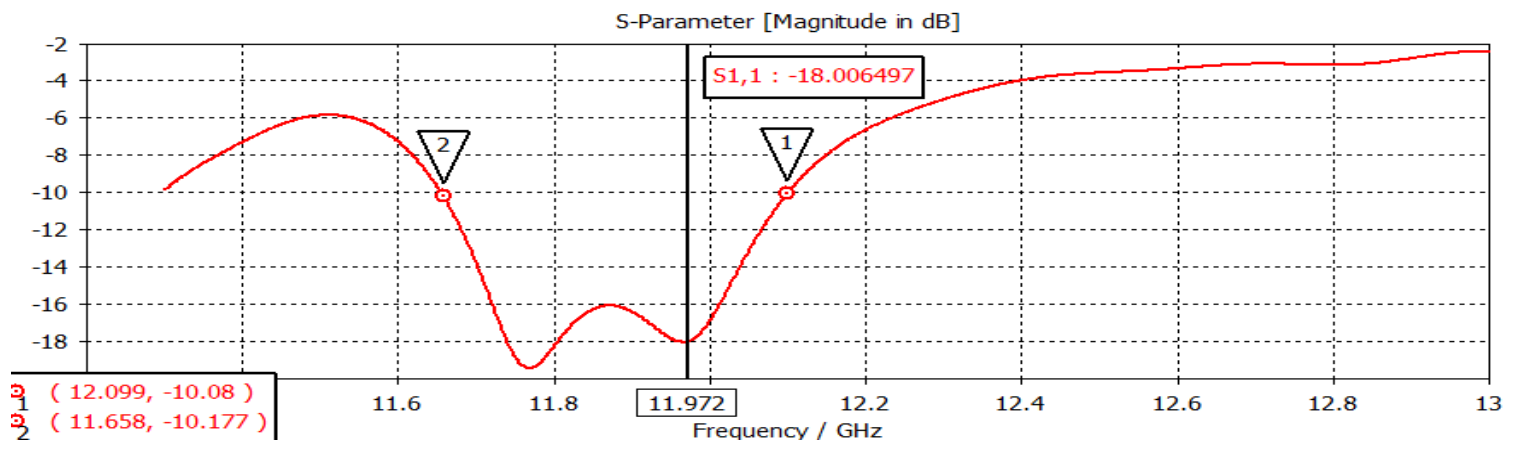

Gambar 5. Return Loss hasil simulasi 
Desain dan Implementasi antena VSAT bergerak dengan flat array berbasis mikrostrip pada frekuensi downlink pita Ku-band

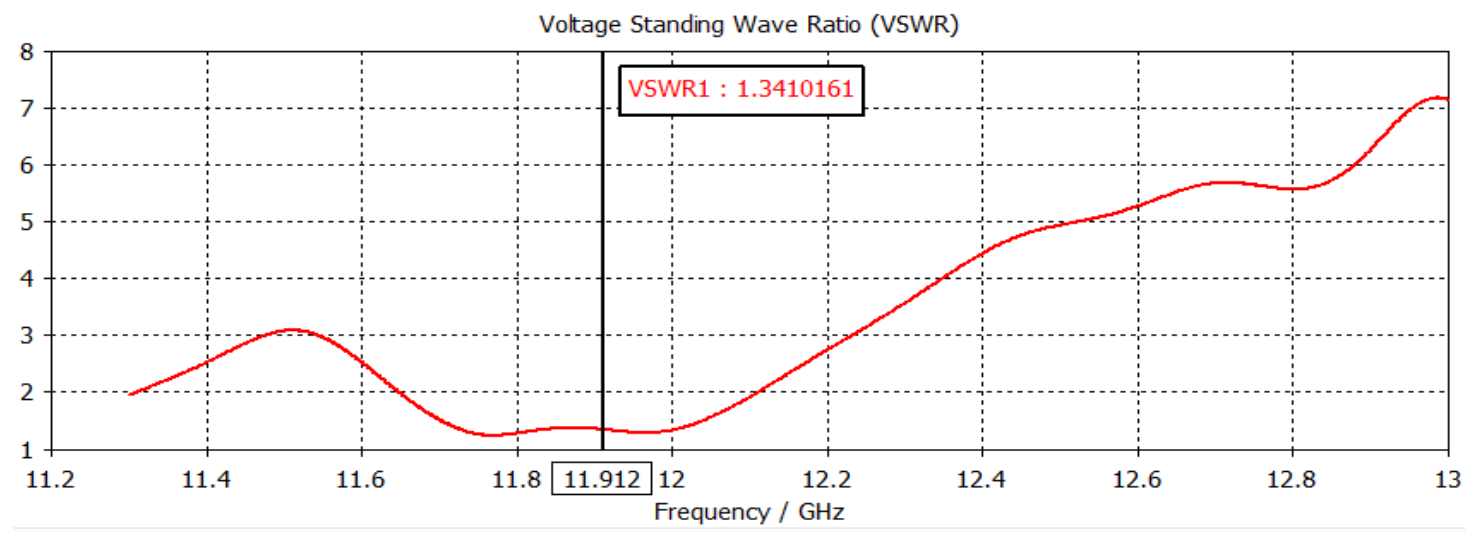

Gambar 6. VSWR hasil simulasi

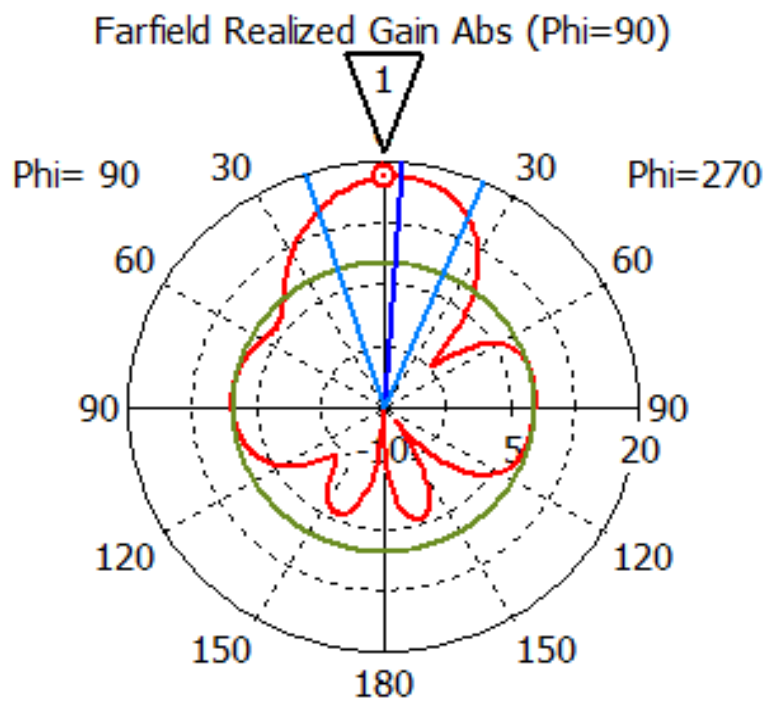

Theta / Degree vs. dB
— farfield $(f=12)$ [1]

Frequency $=12$

Main lobe magnitude $=18.2 \mathrm{~dB}$

Main lobe direction $=4.0 \mathrm{deg}$.

Angular width $(3 \mathrm{~dB})=40.9 \mathrm{deg}$.

Side lobe level $=-10.4 \mathrm{~dB}$

\section{Gambar 7. Pola Radiasi dan Gain hasil simulasi}

Nilai return loss pada frekuensi 11,97 sebesar $-18 \mathrm{~dB}$, VSWR bernilai 1,34 dan gain bernilai $18,2 \mathrm{~dB}$. Nilai-nilai ini telah sesuai dengan spesifikasi antena yang telah ditentukan.

\subsection{Hasil pengukuran}

Berdasarkan hasil simulasi antena mikrostrip array 2x16 ini, maka selanjutnya adalah pengujian secara langsung dengan pengukuran return loss, VSWR dan gain. 
Madiawati, H., Suryana, J.

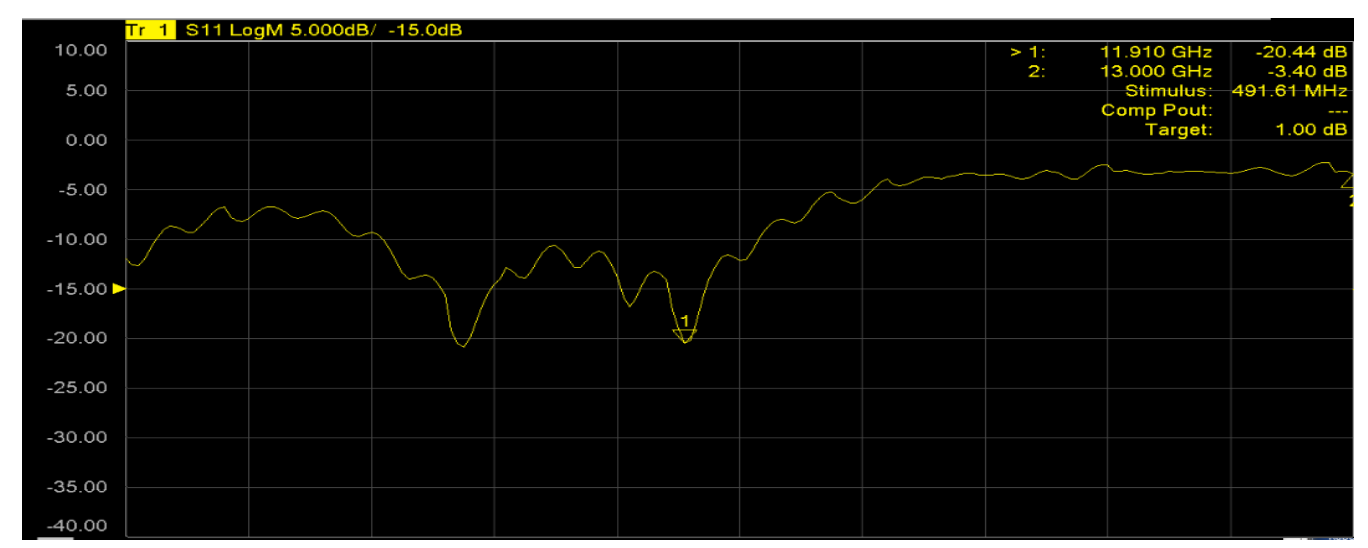

Gambar 8. Return Loss hasil pengukuran

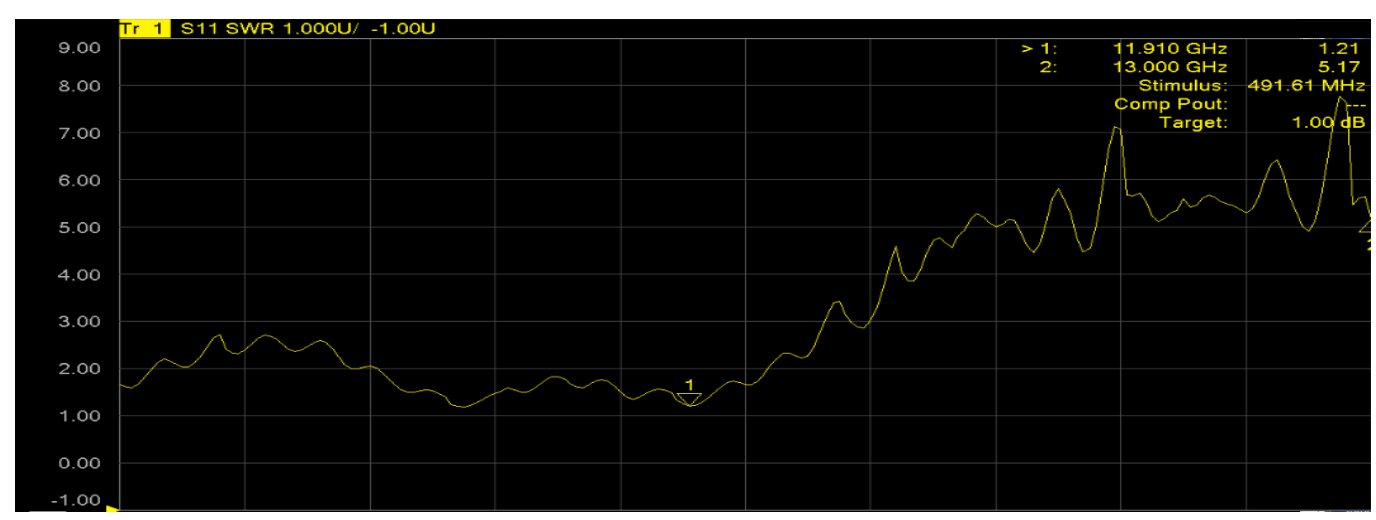

Gambar 9. VSWR hasil simulasi

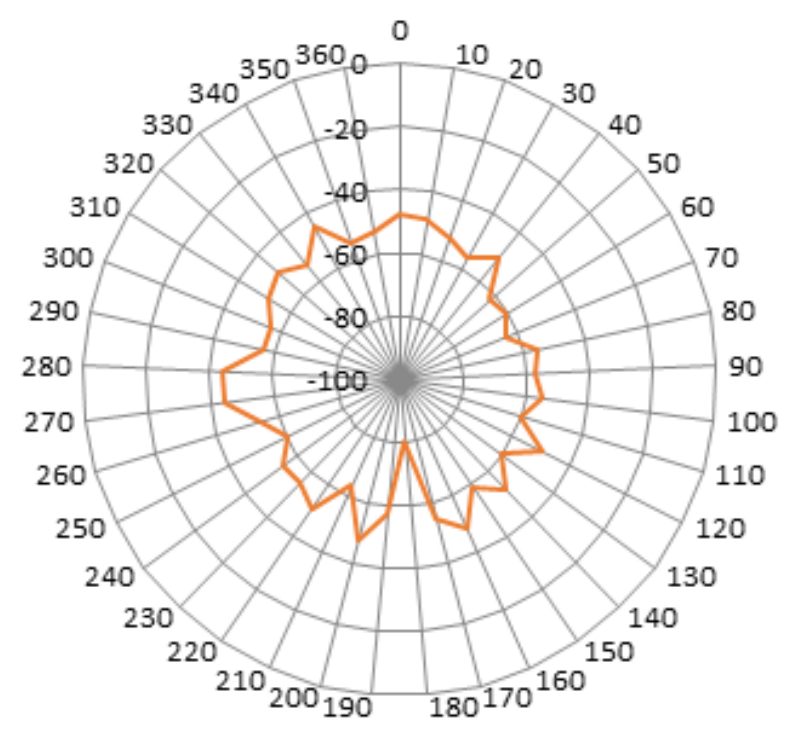

Gambar 10. Pola radiasi hasil simulasi

Dari hasil pengukuran diperoleh nilai return loss sebesar $-20,44$ pada frekuensi $11,9 \mathrm{GHz}$, VSWR 1,21 dan gain 18,69 dB. Nilai yang diperoleh dari hasil pengukuran tidak jauh berbeda dibandingkan dengan simulasi. Selisih nilai untuk return loss sebesar 2,44 dB, VSWR 0.13 dan gain $0,49 \mathrm{~dB}$. Hal ini disebabkan oleh adanya perbedaan nilai $\varepsilon_{r}$ pada perancangan dengan pabrikasi dan pengukuran yang tidak dilakukan pada ruang anechoic chamber. 
Desain dan Implementasi antena VSAT bergerak dengan flat array berbasis mikrostrip pada frekuensi downlink pita Ku-band

Namun, meskipun ada sedikit perbedaan nilai, hasil ini telah memenuhi spesifikasi perancangan yang telah ditentukan.

\section{KESIMPULAN}

Setelah melakukan proses perancangan, simulasi, pabrikasi, pengukuran dan analisa dapat diambil kesimpulan :

1. Penulis telah berhasil merancang sebuah antena mikrostrip array $2 \times 16$ elemen sebagai antena penerima dengan nilai return loss $-18 \mathrm{~dB}$ pada frekuensi $11,97 \mathrm{GHz}$, VSWR 1,3 dan gain 18,2 dB. Hasil simulasi ini telah memenuhi spesifikasi yang telah ditentukan.

2. Penulis telah berhasil merealisasikan antena penerima dengan nilai return loss $-20,44 \mathrm{~dB}$ pada frekuensi $11,9 \mathrm{GHz}$, VSWR 1,2 dan gain 18,69 dB. Hasil pengukuran ini telah memenuhi spesifikasi yang telah ditentukan.

\section{UCAPAN TERIMA KASIH}

Penulis mengucapkan terimakasih kepada bapak Joko Suryana selaku dosen radar teknik telekomunikasi ITB atas saran dan dukungan dalam menyelesaikan jurnal ini dan juga ucapan terimakasih kepada Maulana Randa atas bantuan teknisnya dalam mempersiapkan dan pengujian antena di laboratorium Balitbang Kemenhan.

\section{DAFTAR RUJUKAN}

Xiang, H., Jiang, X. (2009). Design of a high gain low sidelobe microstrip antenna array at Ku-band. Journal IEEE Communications and Mobile Computing. 1: 29-32.

Balanis, C., A. (1982). Antenna Theory : Analysis and Design, second edition, Haper \& Row. Publisher. New York.

Xing, J \& Yiming, L. (2013). A 128-element Microstrip Array Antenna at Ku-band for Satellite Communication. Journal IEEE Communications and Networking. 266-270.

Suryana, J., Sugihartono. (2013). Design and Realization of Flat Mobile VSAT Antenna for Ku/Kaband Satellite Communications with Auto-beam Steering Capability. Journal IEEE Information and Communication Technology. 316-321.

James, J,R. \& Hall, P,S.(1989). Handbook of Microstrip Antennas, London: Peter Peregrines

Rambe \& Hanafiah,A. (2008). Rancang Bangun Antena Mikrostrip Patch Segiempat Planar Array 4 Elemen Dengan Pencatuan Aperture-Coupled Untuk Aplikasi CPE Pada WIMAX. Jakarta: Universitas Indonesia.

Fahrazal, M.(2008). Rancang Bangun Antena Mikrostrip Triple- Band Linier Array 4 Elemen untuk Aplikasi Wimax. Jakarta: Universitas Indonesia.

Hasan.(2014). Penjelasan Spektrum Frekuensi. Dipetik pada 3 May 2016 dari http://allabout-telecommunication.blogspot.co.id/2014/10/penjelasan-tentang-spektrum frekuensi.html 